\title{
トラック輸送の経路選択モデルによるモーダルシフト分析
}

\section{Modal-shift Analysis on Route Choice Model for Truck Transportation}

永岩 健一郎*・松尾 俊彦**

\author{
Kenichiro NAGAIWA and Toshihiko MATSUO
}

\begin{abstract}
Modal shift from truck to railway or ship is very important policy to achieve the Kyoto protocol's targets in Japan. In particular, ferry and Roll-on/Roll-off ship have been paid attention as a mean of realizing intermodalism. Therefore, a lot of researchers have shown the thesis about modal shift, though they have analyzed the mode choice factor of ferry, container ship and rail way in the restricted zone. However, they have not analyzed the factor of ferry and Roll-on/Roll-off ship.

In this paper, the authors studied on the route choice model of the truck for modal shift. Firstly, the authors will show a route choice mode with multi-nominal logit model. Secondly, we will investigate the factor of route choice. Finally, we will describe the effective policy for the modal shift and the reverse modal shift from the viewpoint of policy.
\end{abstract}

Keywords : efficiency transportation, modal shift, route choice logit model, ferry and lift on lift off ship キーワード: 能率運送、モーダルシフト、経路選択ロジットモデル、RORO 船

\section{1. はじめに}

わが国では、1990 年比で 2020 年までに温室効果ガ スの排出を $25 \%$ 削滅することを表明し、2001 年 7 月の 新総合物流施策大綱では、2010 年までにモーダルシフ 卜化率が 50\%を超えることを目標とした。しかし、消 費者ニーズの高度化や多様化に応えるため、トラック におけるドアツードアの輸送が多くなり、輸送距離が 伸びている。これをトンキロベースでみると、2001 年 度に 53.9\%だったトラックの輸送シェアは、2008 年度 には $62.1 \%$ まで高まり、モーダルシフトは一向に進ん でいないことを示している(1)。

しかしながら、トラック輸送に大きく依存する輸送 構造は、地球温暖化や大気污染、騒音・振動問題、交 通事故や労働力不足など多くの課題があり、モーダル シフトを促進させる必要性がある。

そこで、本研究では、トラックで輸送される貨物を 船舶にシフトさせるのではなく、トラックそのものを
海上にシフトさせる方が、より抵抗が少ないと考え、 モーダルシフトの受け入れ先をフェリーと RORO 船に 絞り検討することにした。そのため、フェリーとRORO 船利用の発着地と競合するトラック輸送の貨物を対象 として、輸送経路選択における距離や出荷ロット、品 目などに関する離散選択モデルを構築し、輸送経路選 択における要因の抽出や影響を与える变数の弾力性効 果を計測し、フェリー・RORO 船の利用が促進するかの 示唆を得ることを目的とする。

\section{2. 先行研究の内容と本研究の特徵}

これまでの研究報告では、モーダルシフトについて、 数理モデルを使って検討したものはあまり見られない が、高田ら ${ }^{(2)}$ は集計ロジットモデルを用いて、県単 位の貨物流動について分析している。これは、輸送距 離や時間・品目、それにタリフ・ベースではあるが運 賃まで考慮した分析である。ただし、使用したデータ が、県単位のマクロベースのデータであることと、内

* 正会員 広島商船高等専門学校（干725-0231 広島県豊田郡大崎上島町束野 4272-1） nagaiwa@hiroshima-cmt. ac. jp

** 正会員 東海大学海洋学部（干424-8610 静岡県静岡市清水区折戸 3-20-1）matsuo@scc. u-tokai.ac. jp 
航船を扱っているが、これにはコンテナ船も含まれて おり、船種は意識されていない。

家田ら ${ }^{(3)}$ も県単位のマクロデータを使い、営業用 トラック、鉄道、海運という3 種類の輸送機関選択を 集計ロジットモデルで検討しているが、船種は考慮さ れていない。

田中ら (4) も集計ロジットモデルを利用して、品目 毎にフェリー、コンテナ船、RORO 船、鉄道、そしてト ラックという輸送機関選択モデルを構築して、フェリ 一の運賃を割安にした場合のモーダルシフトについて 考察を加えている。しかし、トラックは10トントラッ クのみを対象としている。

尹ら ${ }^{(5)}$ の研究では、トラック (宅配等混載と一車 貸切を合わせたもの）とフェリー、またトラックと鉄 道コンテナという輸送機関選択について非集計ロジッ トモデルを用いて検討しているが、ここでもトラック は営業用のみであり、船舶についてもフェリーのみで ある。

伊藤 ${ }^{(6)}$ の研究では、品目によって輸送手段・経路 が異なると考えられる北海道発域外向け内貿ニニット 貨物を対象として、輸送経路選択の要因分析を判別分 析によって行っている。また、ランダム・パラメータ・ ロジットモデルを適用した研究 ${ }^{(7)}$ もなされているが、 対象地域は文献（6）と同様である。

以上のように、国内輸送手段や経路選択に関する 分析については、従来から数多くの研究が行われてお り、離散選択モデルを用いて分析している研究もある。 しかし、それらは特定の地域間を輸送対象としている。 また、フェリーや ROR0 船はトラックやトレーラがその まま自走で乗り込むため、トラックの種別によっても 利用する経路や海上輸送機関の違いがあると思われる が、これを考慮していない。
そこで、筆者らはフェリーや RORO 船、コンテナ船な どの船種とトレーラや営業用 (宅配等混載) トラック などの輸送機関分担に関する多群判別モデル構築 (8) や一般道路を走行するトラックとフェリーとの輸送経 路分担に関する非集計二項ロジットモデルの構築 ${ }^{(9)}$ を通して、陸路から海路へのモーダルシフトの検討を 行ってきた。そこでは、トラックの種別によって利用 する経路に違いのあることが分かった。しかし、輸送 機関毎のデータ数に大きな開きがある場合は、的中率 の高いモデルが構築できないことや高速道路のデータ が淮備できなかったことなどの課題を残した。したが って、地域間を特定せず、トラックの種別も考慮し、 また高速道路も経路に入れた離散選択モデルを構築し、 モデルの再現性を実証するとともにフェリー・RORO 船 利用を促進する要因を分析する点に本研究の特徵があ ると言えよう。

\section{3. フェリー・RORO 船とトラック輸送の競 合輸送構造}

\section{1 贷物の平均輸送距離および平均ロット}

Table 1 に、2005 年に実施された全国貨物純流動調査 (物流センサス) の3 日間調査データから、トラック 輸送の県間流動における一般道利用、高速道路利用お よびフェリー・ROR0 船利用の輸送距離と貨物の平均口 ットを示した。ただし、貨物のロットについては、ば らつきと偏りが大きいため、感覚的に実態を理解しや すいものとして幾何平均值も示した ${ }^{(10)}$ 。ただし、物流 センサスには距離に関するデータがないので、4. 1 節 で説明するデータにより算出している。

$\mathrm{RORO}$ 船の輸送距離が陸上も含めて $1,000 \mathrm{~km}$ 以上にな っているのに対して、フェリーはやや短く、949km で ある。さらに、RORO 船は貨物の発着地と利用する港湾

Table 1 Transportation Distance and Lot of Cargo

\begin{tabular}{|c|c|c|c|c|c|c|c|}
\hline \multirow{3}{*}{ Transportation } & \multicolumn{5}{|c|}{ Distance $(\mathrm{km})$} & \multicolumn{2}{|c|}{ Lot of Cargo(ton) } \\
\hline & \multirow{2}{*}{$\begin{array}{c}\text { Distance } \\
\text { (roadway) }\end{array}$} & \multicolumn{4}{|c|}{ distance } & \multirow{2}{*}{$\begin{array}{c}\text { Arithmetic } \\
\text { Mean } \\
\text { Local road/Highway }\end{array}$} & \multirow{2}{*}{$\begin{array}{c}\text { Geometric } \\
\text { Mean } \\
\text { Local road/Highway }\end{array}$} \\
\hline & & access & $\begin{array}{c}\text { Seaway } \\
\text { Highway }\end{array}$ & egress & Total & & \\
\hline Ferry & - & 112.7 & 697.9 & 138.4 & 949.0 & 5.275 & 0.249 \\
\hline RORO & - & 65.4 & 866.1 & 92.6 & 1024.0 & 27.569 & 7.935 \\
\hline Private Truck & 107.2 & 33.0 & 95.1 & 31.4 & 159.5 & $4.846 / 2.120$ & $0.375 / 0.452$ \\
\hline Consolidated $^{1)}$ & 388.7 & 31.9 & 407.8 & 38.4 & 478.1 & $0.156 / 0.211$ & $0.034 / 0.046$ \\
\hline Charterd $^{2 y}$ & 240.8 & 46.2 & 254.5 & 41.6 & 342.3 & $7.356 / 6.195$ & $2.099 / 2.045$ \\
\hline Trailer & 251.2 & 64.8 & 212.3 & 48.0 & 325.1 & $28.62 / 20.729$ & $14.055 / 10.192$ \\
\hline
\end{tabular}

Note: 1) commercial truck of TAKUHAI(door to door service) and cosolidated

2) chartered commercial truck

Source: investigated data of three days of logistics census (2005) 
までの距離がフェリーより短いことに特徴がある(11)。 そして、ロットもフェリーの算術平均で 4 倍強、幾何 平均では 30 倍強と大きなものとなっている。

一方、トラックの平均輸送距離は長くても $400 \mathrm{~km}$ 程 度までで、営業用、トレーラ、自家用の順となる。た だし、ロットはトレーラの平均值が一般道利用の場合 28.62 トン、高速道路利用の場合 20.73 トンと他の種 別のトラックより一桁以上大きいものである。

国土交通省「自動車輸送統計年報」 ${ }^{(12)}$ からも、トラ ック輸送のトンキロベースでは、輸送距離の長距離化 を背景に輸送量が増加の傾向を示している。

したがって、輸送距離とロットから見れば、RORO 船 はフェリーに比較して発着地に近い港湾を利用し、大 ロット貨物輸送を担当している。そして、トレーラも トラックの中ではロットが大きなものを担当している。

このように、フェリーや・RORO 船利用によるモーダ ルシフトを検討する場合は、トラックの種別や船種を 意識する必要がある。

\section{2 出荷時のトラック種別と品目の特徴}

フェリー・RORO 船利用に执ける出荷時のトラックの 種別、品目とロットを Table 2 に示す。これを見ると、 フェリー・RORO 船を利用するトラックの傾向が読み取 れる。

まず、フェリーが利用されるのは、宅配等混載の割 合が $58 \%$ と多く、次に、一車貸切の $22.7 \%$ となってい る。また、品目においては第 6 分類（紙、パルプ、㵶 維、砂糖）が多く、次いで第 7 分類（書籍、衣類、日 用品）、第 5 分類（セメント、ガラス、石油、化学工業 品）、第 4 分類 (鉄鋼、自動車、機械類)となっている。

一方、ROR0 船はトレーラの割合が $61.5 \%$ と多く、次 に一車貸切の $34.2 \%$ となている。また、品目におい ては、第 6 分類と第 4 分類で半数以上となっている。

したがって、フェリー・RORO 船へのモーダルシフト を考える場合には、品目についても意識する必要があ る。

\section{4. 輸送分担モデルの構築}

\section{1 データ}

前章で述べた基礎的分析をもとに、本研究では、2005 年の物流センサスデータ (3日間調査データ) を用い、 県間流動で、かつフェリー・RORO 船の利用のあった発 着地（生活圈）を選択し、フェリー・RORO 船とトラッ クのデー夕を分析用データとした。

なお、距離については、物流センサスには示されて いないので、次のようにデータを準備した。

まず、一般道路距離は『全国貨物自動車営業キロ程 図』(14)を利用して、主要国道ネットワークから県庁所 在地などの各県の接続ポイント $(1,038$ 点) を抽出し 最短路を求めた。

また、高速道路距離は『高速道路料金表』(15) を利用 して、物流センサスデータに記載の IC (1,351 所) 間 の距離と接続関係から最短路を求めた。生活圈から利 用した IC までの一般道距離は、IC から最寄りの一般 道の接続ポイントまでの距離と一般道ネットワークか ら算出している。

さらに、船舶の航海距離については『内航距離表』(16) から、海上接続点 420 力所と、物流センサスで使用さ れている 866 港を用いたネットワークを作成し、これ を利用した。なお、この海上ネットワークによる航海 距離は、実際の 57 のフェリ一航路長と比較したところ、 誤差は平均 1.95\%（標準偏差 4.82）とわずかな值に収 まるものとなった。

\section{2 モデル}

離散型経路選択モデルとしては、判別モデルやロジ ツトモデルが利用されるが、最近では、個体の選択が 選択肢から得られるランダム効用に基づいて確率的に 行われるとするロジットモデルがよく利用される ${ }^{(17) 。 ~}$ しかしながら、ロジットモデルはデータ数に偏りが ある場合には、近似の精度が悪くなり、無視できな いバイアスを持つことが知られている。

本研究では、RORO 船のデータ数が 827 と少ないため、

Table 2 Type of Truck cage item and bot's at origin

\begin{tabular}{|c|c|c|c|c|c|c|c|c|c|c|c|c|}
\hline \multirow{2}{*}{ Transportation } & \multirow{2}{*}{$\begin{array}{c}\text { Type of Truck } \\
\text { at Origin }\end{array}$} & \multirow{2}{*}{$\begin{array}{c}\text { Utilization } \\
\text { rate }\end{array}$} & \multicolumn{9}{|c|}{ Cargo Item ${ }^{(13)}$} & \multirow{2}{*}{ Lot } \\
\hline & & & I & II & III & IV & $\mathrm{V}$ & VI & VII & VII & IX & \\
\hline \multirow{4}{*}{ Ferry } & Private & 0.40 & 0.1 & 0.0 & 0.0 & 0.1 & 0.0 & 0.1 & 0.0 & 0.0 & 0.0 & 3.06 \\
\hline & Consolidated & 58.06 & 4.6 & 0.0 & 0.0 & 12.0 & 12.5 & 14.2 & 13.3 & 0.3 & 1.1 & 0.20 \\
\hline & Chartered & 22.70 & 4.6 & 0.1 & 0.0 & 5.8 & 4.1 & 5.6 & 2.1 & 0.1 & 0.3 & 6.58 \\
\hline & Trailer & 18.84 & 3.4 & 0.5 & 0.1 & 5.4 & 3.2 & 5.3 & 0.8 & 0.1 & 0.2 & 19.08 \\
\hline \multirow{4}{*}{ RORO } & Private & 0.4 & 0.0 & 0.0 & 0.0 & 0.4 & 0.0 & 0.0 & 0.0 & 0.0 & 0.0 & 12.68 \\
\hline & Consolidated & 1.8 & 0.2 & 0.0 & 0.0 & 0.4 & 0.0 & 1.2 & 0.0 & 0.0 & 0.0 & 0.36 \\
\hline & Chartered & 34.9 & 1.7 & 0.0 & 0.0 & 17.5 & 6.9 & 6.4 & 2.2 & 0.2 & 0.0 & 33.30 \\
\hline & Trailer & 62.9 & 1.0 & 0.2 & 0.1 & 24.7 & 4.1 & 29.1 & 3.3 & 0.1 & 0.2 & 24.83 \\
\hline
\end{tabular}


Table 3 に示すようにフェリーと RORO 船は海上利用経 路として合算した。トラック輸送経路としては、一般 道利用、高速道路利用、海上利用を対象とし、以下の ような非集計多項ロジットモデルを用いることとした。 なお、パラメータの推定には統計解析ソフトである SPSS のロジスティクス回帰分析（最尤推定法）を使用 した。

$$
\begin{aligned}
& P_{\text {in }}=\exp \left(V_{\text {in }}\right) / \sum \exp \left(V_{\text {jn }}\right) \quad\left(\mathrm{j} \in \mathrm{A}_{\mathrm{n}}\right) \\
& V_{\mathrm{in}}=\sum \theta_{\mathrm{k}} X_{\mathrm{ink}} \\
& \text { ただし、}
\end{aligned}
$$

\section{$\mathrm{P}_{\text {in }}$ ：貨物 n が輸送経路 $\mathrm{i}$ を利用する確率 \\ $V_{\text {in }}$ ：輸送経路 $\mathrm{i}$ に対する貨物 $\mathrm{n}$ の効用 $\theta_{\mathrm{k}}:$ 説明変数 $\mathrm{k}$ のパラメータ值}

$\mathrm{X}_{\mathrm{ikn}}$ : 貨物 $\mathrm{n}$ 、輸送経路 $\mathrm{i}$ の $\mathrm{k}$ 番目の説明変数

$\mathrm{A}_{\mathrm{n}}$ : 選択肢集合

\section{3 モデルを構成する変数}

輸送機関を選択寸る要因としては、輸送コストや輸 送時間が大きな影響を与えることは、田中や尹らの先 行研究で示されている。しかし、フェリーやRORO 船は、 大きさも様々であり、乗り組んでいる船員数も当然異 なるため、輸送コストを確定することは容易ではない。 また、海上運賃や高速道路利用料金も、大口利用割引 や時間帯における割引などもあって不明確である。し たがって、明確な輸送コストや運賃をモデルに与える ことは難しい。

一方、輸送時間についてもターミナルでの乗船待ち 時間などにばらつきがあり、明確な数值は得にくい。 そこで、まずモデルに与える変数として、距離を使用 することにした。

なお、利用経路以外の代替経路については、一般道 は、発着生活圈間の最短路、高速道路は作成した高速 道路ネットワークを利用し、発地〜発 IC～着 IC～着 地の距離が最小となり、かつ高速道路利用の距離が、 全体の半分以上を占めるルートを選定した。また、海 上経路は、作成した海上ネットワークを利用し、発地 ～発港湾〜着港湾〜着地の距離が最小となり、かつ船 舶が代表輸送機関となるように、全体の半分以上は海 上輸送距離が占める航路を選定した。

さらに、家田や尹らが注目した貨物のロットも変数 として使用し、ロット毎にトラックの種別に特徴があ るためトラック種別もダミー変数とした。さらには品 目も運賃負担力やフェリー・ROR0 船の利用に特徽があ るためダミー変数として与えた。

\section{4 モデルのパラメータ}

使用したデータとモデルの的中率を Table3 に示寸。 一般道利用が $87.9 \%$ 、高速道路利用が $81.6 \%$ 、海上が $77.9 \%$ であり、全体では $82.9 \%$ と再現性の高いモデル である ${ }^{(18)}$ 。また、各パラメータの推計結果を Table4

\begin{tabular}{|c|c|c|c|c|c|c|}
\hline & \multicolumn{3}{|c|}{ Model } & \multirow[b]{2}{*}{ Total } & \multirow{2}{*}{$\begin{array}{c}\text { hitting } \\
\text { ratio }\end{array}$} \\
\hline & & $\begin{array}{l}\text { Local } \\
\text { road }\end{array}$ & Highway & Seaway & & \\
\hline \multirow{3}{*}{$\begin{array}{c}\text { Using } \\
\text { data }\end{array}$} & Local road & 7,233 & 355 & 644 & 8,232 & $87.9 \%$ \\
\hline & Highway & 1,003 & 5,953 & 335 & 7,291 & $81.6 \%$ \\
\hline & Seaway & 1,127 & 232 & 4,788 & 6,147 & $77.9 \%$ \\
\hline \multicolumn{2}{|c|}{ Total } & 9,363 & 6,540 & 5,767 & 21.670 & $82.9 \%$ \\
\hline
\end{tabular}
に示す。

Table 3 Using data and Hitting ratio

\begin{tabular}{|c|c|c|}
\hline Explanatory variable & $\begin{array}{l}\text { Local road } \\
\text { (Wald) }\end{array}$ & $\begin{array}{l}\text { Highway } \\
\text { (Wald) }\end{array}$ \\
\hline Private Truck & $\begin{array}{r}2.471 \\
(43.779)\end{array}$ & $\begin{array}{r}2.504 \\
(34.880)\end{array}$ \\
\hline Consolidated Truck & $\begin{array}{r}4.190 \\
(1066.122) \\
\end{array}$ & $\begin{array}{r}4.392 \\
(577.654) \\
\end{array}$ \\
\hline Chartered Truck & $\begin{array}{r}2.774 \\
(506.739)\end{array}$ & $\begin{array}{r}3.243 \\
(337.287)\end{array}$ \\
\hline Local road distance & $\begin{array}{r}.008 \\
(326.473)\end{array}$ & $\begin{array}{r}.008 \\
(352.085)\end{array}$ \\
\hline Access distance to IC & $\begin{array}{r}-.019 \\
(80.862) \\
\end{array}$ & $\begin{array}{r}.044 \\
(840.980)\end{array}$ \\
\hline Highway distance & $\begin{array}{r}-.015 \\
(1414.037) \\
\end{array}$ & $\begin{array}{r}-.018 \\
(1692.918)\end{array}$ \\
\hline Egress distance from IC & $\begin{array}{r}-.123 \\
(1108.504)\end{array}$ & $\begin{array}{r}.024 \\
(365.146)\end{array}$ \\
\hline Access distance to port & $\begin{array}{r}-.007 \\
(240.199)\end{array}$ & $\begin{array}{r}-.007 \\
(213.309)\end{array}$ \\
\hline Seaway distance & $\begin{array}{r}.007 \\
(1529.753) \\
\end{array}$ & $\begin{array}{r}.009 \\
(1773.147) \\
\end{array}$ \\
\hline Egress distance from port & $\begin{array}{r}-.006 \\
(194.180) \\
\end{array}$ & $\begin{array}{r}-.010 \\
(385.644) \\
\end{array}$ \\
\hline Lots & $\begin{array}{r}-.016 \\
(22.105)\end{array}$ & $\begin{array}{r}-.024 \\
(26.873)\end{array}$ \\
\hline No.1 classified cargo item & $\begin{array}{r}.951 \\
(12.594)\end{array}$ & $\begin{array}{r}.217 \\
(.634)\end{array}$ \\
\hline No. 2 classified cargo item & $\begin{array}{r}1.852 \\
(6.656)\end{array}$ & $\begin{array}{l}-. .713 \\
(.347)\end{array}$ \\
\hline No.4 classified cargo item & $\begin{array}{r}.970 \\
(14.913)\end{array}$ & $\begin{array}{l}.202 \\
(.633)\end{array}$ \\
\hline No.5 classified cargo item & $\begin{array}{r}.965 \\
(14.565) \\
\end{array}$ & $\begin{array}{r}-.001 \\
(.000)\end{array}$ \\
\hline No. 6 classified cargo item & $\begin{array}{r}.803 \\
(10.086) \\
\end{array}$ & $\begin{array}{r}-.268 \\
(1.085) \\
\end{array}$ \\
\hline No.7 classified cargo item & $\begin{array}{r}.955 \\
(14.136) \\
\end{array}$ & $\begin{array}{r}-.649 \\
(6.230)\end{array}$ \\
\hline No.8 classified cargo item & $\begin{array}{c}-2.462 \\
(8.430) \\
\end{array}$ & $\begin{array}{r}-1.411 \\
(4.809) \\
\end{array}$ \\
\hline Constant & $\begin{array}{r}.573 \\
(4.006) \\
\end{array}$ & $\begin{array}{l}-.260 \\
(.681)\end{array}$ \\
\hline$-2 \log$ likelihood First/last & \multicolumn{2}{|c|}{$19731.000 / 19734.841$} \\
\hline Cox-Snell R2 & \multicolumn{2}{|l|}{.720} \\
\hline Nagelkerke $\quad$ R2 & \multicolumn{2}{|l|}{811} \\
\hline
\end{tabular}

Table 4 Parameter of Logit Model 


\section{5 モ一ダルシフトの要因}

一般道と高速道路モデルのパラメータの符号が、高 速道距離、発着港アグレス・イグレス、ロットのよう に同時にマイナスの場合は、その変数がより大きくな ると海上を選択寸る確率が高くなり、逆に、一般道距 離、航路長のように同時にプラスの場合はその変数が 大きくなると陸上を選択する確率が高くなる。

そこで、 $\mathrm{t}$ 值とほぼ同等であるWald 検定量を見なが ら輸送経路選択について考察を加えるならば、まず、 輸送経路を選択するには、航路長が大きく影響してい ることが分かる。航路長は、一般道・高速道路モデル ともに係数がプラスであるので、航路長が長くなれば 一般道か高速道路が利用される傾向を示す。

次に、高速道路の距離が影響し、一般道・高速道路 モデルともに係数がマイナスであるので、高速道距離 が長くなれば海上経路が選択される傾向となる。

よって、一般道距離や利用する高速道距離が長くな るか航路長が短くなると海上を利用し、その逆である と陸上を利用する現状を良く表現しているモデルとな っている。これらの点は、家田や尹仙美らの研究結果 と同様の結果となっている。

さらに、品目については、係数がプラスの品目は陸 上の選択確率を上げることを意味し、マイナスの品目 はその選択確率を下げることを意味する。例えば、第 8 分類は一般道モデル、高速道モデルともにマイナス であり、海上利用の確率を上げる品目であるといえる。

そこで、Wald 検定量の大きい宅配便等混載トラック の第 7 分類品目において、航路長を変化させた時の各 経路の選択確率の変化を Fig.1 に示す。航路長を $20 \%$ 短縮すると海上利用の確率が他の経路より高くなるこ とを示しており、航路長の短縮はモーダルシフトに効 果があることが判る。

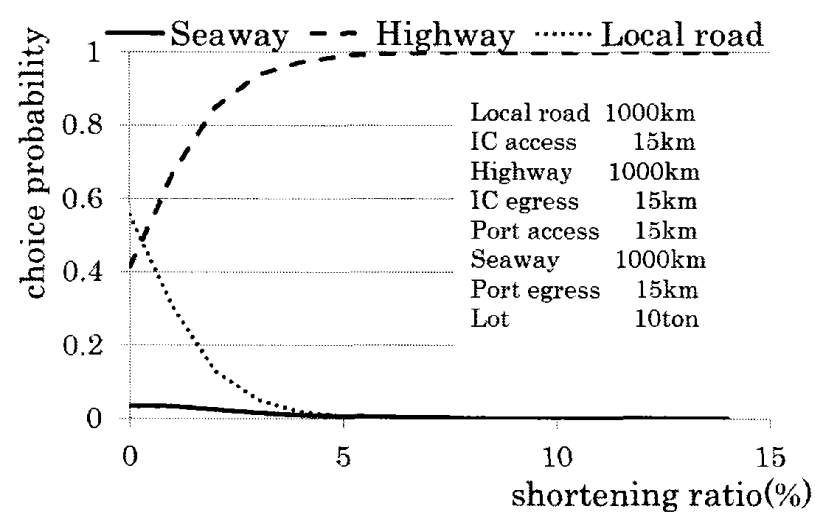

Fig.1 Choice probability by shortening of Seaway

次に、宅配便等混載トラックの第 7 分類品目におい て、高速道距離を変化させた時の各経路の選択確率の 変化を Fig.2 に示寸。高速道距離の短縮は、逆モーダ
ルシフトに非常に影響があることが良く判る。

先に述べたように、船舶へのモーダルシフトは、船 舶の高速化と運賃の值下げが効果的という。また、家 田や尹らの研究では、ロットを大きくすれば、船舶の 利用傾向が高まるという。しかし、ロットを大きくす ることについては、メーカなどの何主が行うことであ り、輸送業者が実施できることは難しいと考えられる。 そこで、船舶の高速化や運賃の值下げ、あるいは高 速道路の利用料金の変化が、経路選択にどのような影 響を与えるかを検討することが重要となるう。しかし、 本研究ではモデルの説明変数にこのような政策変数を 用いていないので、次のように考えることとした。す なわち、船舶の高速化や運賃の値下げは、同一発着港 閒の航路長が疑似的に短縮したと考え、また同様に、 高速道路利用料金の值下げについては、同一発着 I C 間で高速道距離が疑似的に短縮したと置き換えシミュ レーションを試みることにした ${ }^{(19)}$ 。

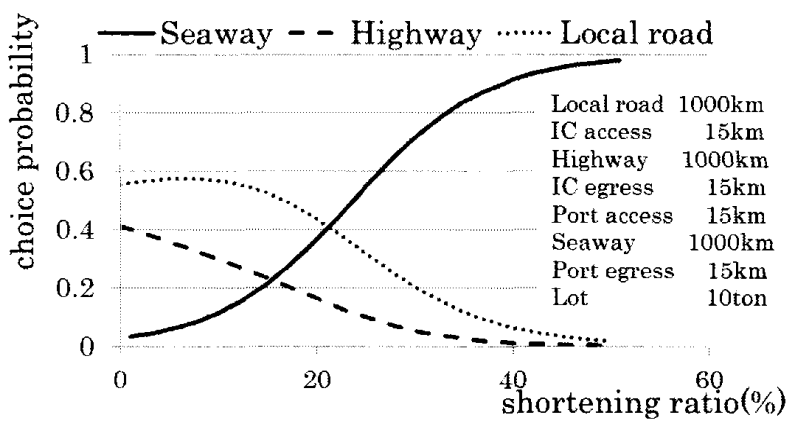

Fig.2 Choice probability by shortening of Highway

\section{5. 感度分析と考察}

\section{1 航路長の抵抗変化に伴うモーダルシフト乓}

航路長を短縮（船舶の高速化や運貨の值下げ）した ときのモーダルシフトに対する効果を、トラックの種 別ごとに（3）式により求めることにした。すなおち、 経路選択モデルから得られた各経路における総トンキ 口から、航路長を短縮することによって経路が変化し たときの総トンキロの変化量を求めた。この結果を、 横軸が航路長の短縮率、縦軸をモーダルシフト率とし て Fig.3 に示す。なお、経路の選択には、選択確率の大 きい経路を利用経路とした。

$$
\begin{aligned}
& \left.\mathrm{MS}_{\mathrm{ij}}=100 \times\left(\mathrm{TK}_{\mathrm{ij}}-\mathrm{TK}_{\mathrm{i} 0}\right) / \sum \mathrm{TK}_{\mathrm{i} 0}\right) \quad\left(\mathrm{i} \in \mathrm{A}_{\mathrm{n}}\right) \\
& \text { ただし、 } \\
& \mathrm{MS}_{\mathrm{ij}} \text { : トラックの種別 } \mathrm{i} \text { の短縮率 } \mathrm{j} \text { のときのモーダルシ } \\
& \text { フト率 } \\
& \mathrm{Tk}_{\mathrm{ij}} \text { : トラックの種別 } \mathrm{i} \text { の短縮率 } \mathrm{j} \text { のときの総トンキロ }
\end{aligned}
$$

Fig.3 に示すように、モーダルシフト率の最も高いの 

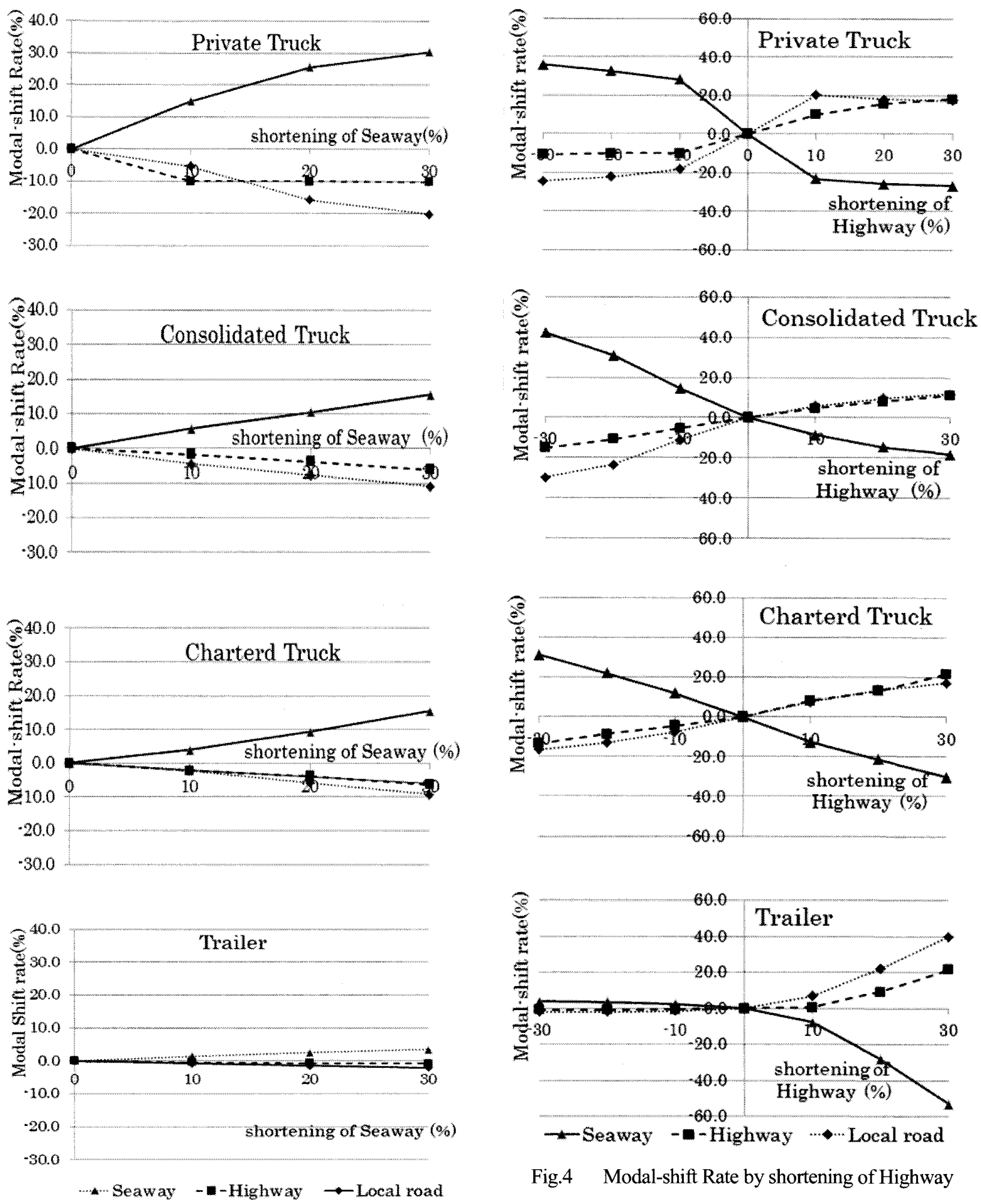

Fig.4 Modal-shift Rate by shortening of Highway

Fig.3 Modal-shift Rate by shortening of seaway

は自家用トラックで、航路長 $10 \%$ の短縮で $15 \%$ のモ 一ダルシフト率となった。また、航路長 30\%の短縮で は 30\%のモーダルシフト率を示している。

宅配等混載トラックと一車貸切トラックは、航路長 10\%の短縮で $5 \%$ 、航路長 20\%の短縮で $10 \%$ の一

\section{ダルシフト率を示している。}

トレーラは航路長を $30 \%$ 短縮しても、3\%程度のモ ーダルシフト率しかなく、航路長の短縮による影響が 小さいことを示している。よって、トレーラは陸上へ のシフトが非常に小さく海上利用の傾向が著しく高い といえる。

このように、トラックの種別によってモーダルシフ 
ト率には特徴があり、モーダルシフト率の大きな車種 に注目して施策を検討寸ると効果が高いことが判る。

\section{2 高速道の抵抗変化に伴うモ一ダルシフト量}

航路長の短縮と同様に高速道距離が変化したときの シフト率の変化量を求めた。Fig.4 に示すように高速道 距離の短縮（利用料金の值下げ）は、陸上への逆モ一 ダルシフトに大きく影響し、延長 (利用料金の值上げ、

Fig.4の横軸が負となる象限）はモーダルシフトを向上 させることを示している。特に、トレーラは高速道距 離を $30 \%$ 短縮すると $25 \%$ 逆モーダルシフト率とな る。また、自家用トラックや一車貸切では、30\%の短 縮で $20 \%$ の逆シフト率、宅配便等混載では $10 \%$ の逆 シフト率となる。したがって、現在実施されているト ラックの深夜割引は、高速道距離の短縮とほぼ同様の 効果があり、逆モーダルシフトにつながるものである。

逆に、高速道距離の延長は、トレーラにはほとんど 影響がないことが判る。自家用トラックは、10\%延長 でシフト率が $30 \%$ となり、非常に効果が高いことが判 る。宅配等混載と一車貸切では、延長率とシフト率が ほぼ同じで、10\%の延長で 10\%のシフト率、30\%の延 長で $30 \%$ のフト率となっており、モーダルシフトに は大きな効果があることを示している。

つまり、本研究の成果により高速道路の短縮・延長 によるモーダルシフトと逆モーダルシフトを定量的に 把握することが可能となった。

\section{6. まとめ}

本研究で得られた知見を整理すれば、以下の 3 点と なる。

(1)多項ロジットモデルの構築により、モーダルシフ トと逆モーダルシフトに対する弾性力分析が可能 となった。

(2)構築したモデルから、フェリー・RORO 船の選択 確率を向上させ、モーダルシフトを促進する条件は、 航路長の短縮（船舶の高速化や運賃の值下げ）と高 速道距離の延長（利用料金の值上げ）であることが 得られた。なお、この効果はトラックの種別によっ て異なることが明らかとなった。

(3)トラック種別では自家用、宅配等混載、一車貸切 を、品目では第 8 分類をモーダルシフトの対象とす ると効果が大きいことが明らかになった。

また、本研究においては、次の課題が残っていると 言えよう。

(1)距離の代わりに、輸送コストや輸送時間を説明変
数に導入するための検討が必要である。

(2)フェリーとRORO 船の選択関係を調査することが必 要である。

なお、本研究は日本学術振興会科学研究費補助金 (C) (2) 課題番号 21560836 の助成を受けて行った研究 成果の一部であることを付記しておく。

\section{注および参考文献}

（1）日本物流団体連合会『数字で見る物流（2010 年度 版)』

（2）高田裕巳 - 渡辺豊 - 山田猛敏 : 海上貨物輸送機関 の利用特性に関する研究、土木計画学研究・講演 集、No. 15(1)、pp. 623-628、1992. 11

（3）家田仁・佐野可寸志・小林伸司：商品価格と流動 ロットに着目した都市間貨物輸送機関分担モデ ル、土木学会論文集、No. 548、pp. 1-10、1996.10

（4）田中淳・柴崎隆一・渡部富博 : 内貿ユニットロー ド貨物の輸送機関分担に関する分析、国土技術政 策総合研究所資料、No. 60、pp. 1-19、2003.3

（5）尹仙美・片山直登・百合本茂：トラック輸送から 鉄道・フェリー輸送へのモーダルシフトモデル、 日本物流学会誌、No. 13、pp. 35-42、2005.5

（6）伊藤秀和：遠隔地における荷主の輸送行動モデル 分析一北海道を例に一、日本物流学会誌、No. 14、 pp. $77-84 、 2006.5$

（7）伊藤秀和：モーダルシフト政策に寄与する貨物輸 送経路選択のモデル分析一ランダム・パラメー タ・ロジット・モデルの適用一、日本物流学会誌、 No. 16、pp. 201-208、2008. 5

（8）永岩健一郎・松尾俊彦：モーダルシフト対象船種 の特徵を考慮した輸送機関分担モデル、広島商船 高等専門学校紀要、第 28 号、pp. 39-43、2006

(9) 松星俊彦・永岩健一郎・篠原正人：中長距離フ工 リーの利用モデルと航路に関する研究、日本物流 学会誌、No. 15、pp33-40、2007

（10）ロットについては外れ值に近い数值も含まれるた め、算術平均值に大きく影響を受ける。その影響 をあまり受けないものとして幾何平均も併記し た。

（11）ROR0 船はインダストリアル・キャリアーの性格 が強く、製紙業などの大口荷主の港湾で荷役を行 うことなどから、貨物輸送の発着地と利用港湾が 近いと思われる。

（12）国土交通省『自動車輸送統計年報』2010 年版

(13) Cargo Item は以下の通りである。 
I : Agricultural and Fishery（農水産品）

II : forest product (林産品)

III : mineral product (鉱産品)

IV : metal and Machine product (金属機械工業品)

$\mathrm{V}$ : Chemical Products (化学工業品)

VI : light industrial products（軽工業品）

VII : miscellaneous industrial products (雑工業品)

VIII : specialty industrial products (特殊品)

IX : others industrial products (その他)

（14）貨物自動車運賃研究会『全国貨物自動車営業キロ 程図』交通日本社版、1998

（15）高速道路調査会『高速道路料金表』2005 年版

（16）日本海運集会所『内航距離表』1992 年改訂版

（17）土木学会『非集計行動モデルの理論と実際』1995 年版

(18)井らの研究では 4 つのモデルを構築しているが、 それぞれ的中率は全体で $0.79 、 0.60 、 0.76 、 0.80$ となっている。本研究では、82.9\%と比較的高い数 值となっており、再現性が高いモデルといえる。

（19）輸送時間や輸送コストは、距離の関数として表現 されることが多い。そこで、輸送機関の高速化は輸 送時間を短くすることで、見方を変えれば経路上の 距離が短縮したと見ることも出来る。また、運賃や 利用料金の值下げは、利用者の負担を軽くすること であり、これも距離が短縮して利用者の負担が軽く なった見ることが出来よう。

\section{質疑応答}

松本浩文（水産大学校）：

平成 20 年度からスタートした高速道路の夜間割引 影響はモーダルシフトへどの様に影響したのか教 えてください。

永岩健一郎：

事前のヒアリング調査によると、高速道路の休日 1,000 円より大きな影響を与えたということです。 本研究では、直接深夜割引は対象としていませんが、 料金割引を高速距離の短縮と相似していると考え れば、高速道路の利用が促進されることは説明でき ます。

篠田岳思 (九州大学) :

経路選択への短縮率の影響をお示し頂きましたが、 モデルで扱われた 9 品目の内どの品目が経路選択 に影響を与えるのかを教えてください。計算が可能 であれば、どの品目を狙いモーダルシフトにつなげ
られるか検討できると考えます。

永岩健一郎：

品目によって選択確率は異なります。第 8 分類品目 がフェリーや RORO 船を指向すると言えます。 